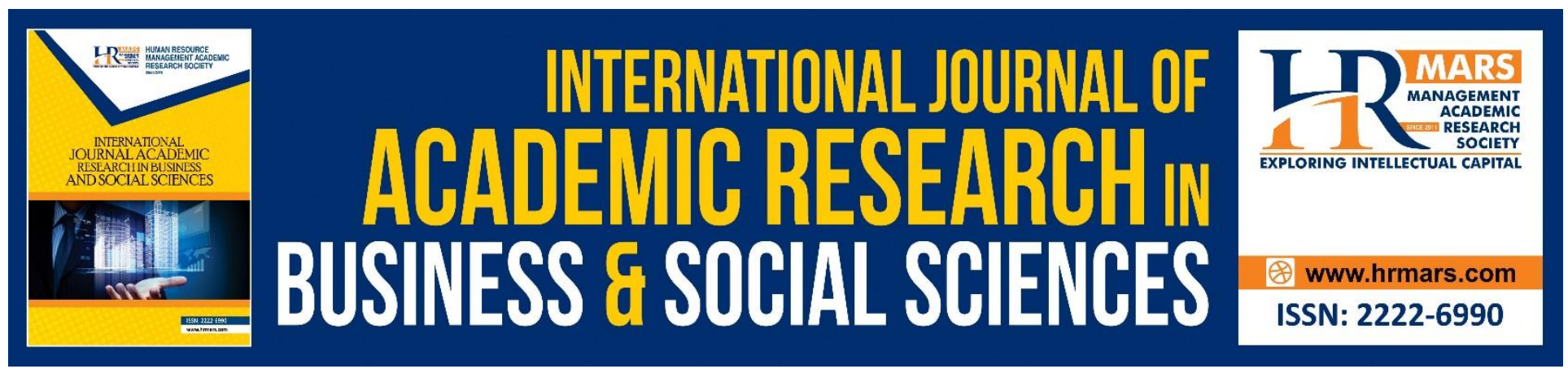

\title{
Intangible of Skills at Tactical Level of Strategy in Malaysia's Counter Insurgency Experience in 1970's
}

Abdul Latif Harun, Nur Farahana Zul Kernain and Nur Surayya Mohd Saudi

To Link this Article: http://dx.doi.org/10.6007/IJARBSS/v9-i1/5867

DOI: $10.6007 /$ IJARBSS/v9-i1/5867

Received: 29 Nov 2018, Revised: 17 Dec 2019, Accepted: 01 Jan 2019

Published Online: 22 Jan 2019

In-Text Citation: (Harun, Kernain, \& Saudi, 2019)

To Cite this Article: Harun, A. L., Kernain, N. F. Z., \& Saudi, N. S. M. (2019). Intangible of Skills at Tactical Level of Strategy in Malaysia's Counter Insurgency Experience in 1970's. International Journal of Academic Research Business and Social Sciences, 9(1), 1288-1297.

Copyright: (C) 2019 The Author(s)

Published by Human Resource Management Academic Research Society (www.hrmars.com)

This article is published under the Creative Commons Attribution (CC BY 4.0) license. Anyone may reproduce, distribute, translate and create derivative works of this article (for both commercial and non-commercial purposes), subject to full attribution to the original publication and authors. The full terms of this license may be seen

at: http://creativecommons.org/licences/by/4.0/legalcode

Vol. 9, No. 1, 2019, Pg. 1362 - 1371

http://hrmars.com/index.php/pages/detail/IJARBSS

JOURNAL HOMEPAGE

Full Terms \& Conditions of access and use can be found at http://hrmars.com/index.php/pages/detail/publication-ethics 


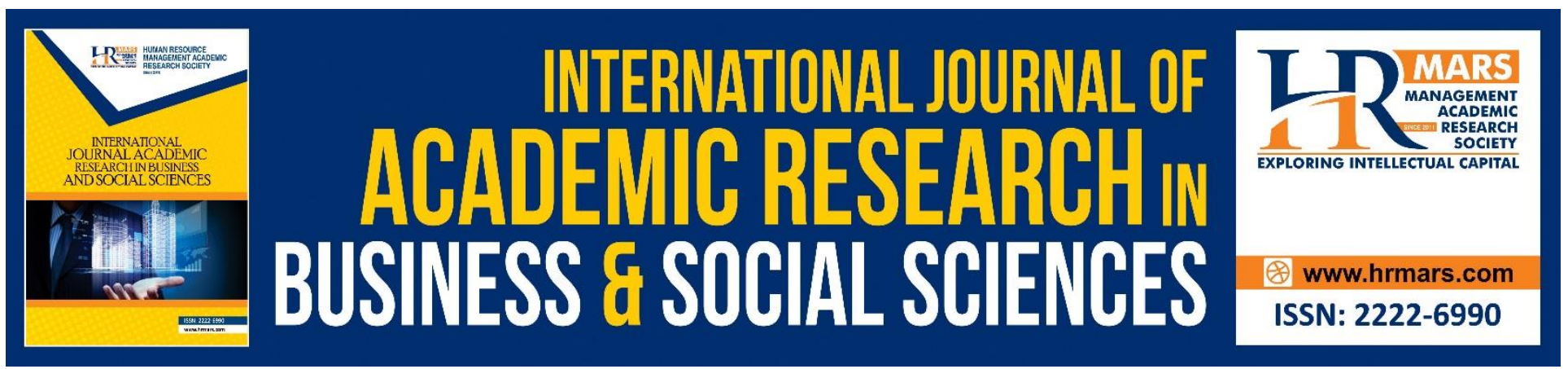

\title{
Intangible of Skills at Tactical Level of Strategy in Malaysia's Counter Insurgency Experience in 1970's
}

\author{
Abdul Latif Harun, Nur Farahana Zul Kernain and Nur Surayya \\ Mohd Saudi
}

National Defense University of Malaysia

\begin{abstract}
Clausewitz famously stated that strategy is done by tactics. At tactical level, both tangible and intangible skills are important for the Malaysian Security Forces (SF) combatting communist insurgents in adverse weather conditions and difficult terrains. This research studies the strategic utility of intangible of skills and its impact on the tactical performance of Malaysian Security Forces personnel during Counter Insurgency campaigns against the armed struggle of the Communist Party of Malaya (CPM) in the 1970's. The key argument profounder by this article is that the tactical effectiveness of Malaysian Security Forces personnel was heavily influenced by the qualities of its men which cannot be quantified such as courage, bravery, morale and leadership. The Counter Insurgency campaign was fought at close range in isolated jungle terrain. Thus, men at tactical level must perform exceptionally well in facing the insurgents at close range with little warning. What provided the tactical edge in such close violent skirmishes was the superior intangible qualities, which had enabled the Malaysian Security Forces personnel to perform tactically better than their foes and ultimately produced immense strategic effects that led to the ultimate defeat of the CPM armed struggle. Intangible of skills performed by men of the past should not left un-notice; instead, it should be further developed and nurtured for within future security forces.
\end{abstract}

Keywords: Intangible of skills, Courage, Bravery, Morale, Leadership, Counter Insurgency, Malaysia's, Security, Tactical level, Strategy.

\section{Introduction}

Malaysia's experience in handling her external defense and internal security situation immediately began after the end of World War 2. It began with the First Malayan Emergency from 1948 to 1960 when the Communist Party of Malaya (CPM) launched its armed offensive with the aim the legitimate government. The British Malaya Administration was established quickly after the war managed to suppress the CPM armed struggle. At the same period, on $31^{\text {st }}$ August 1957 Malaya was given Independence. The security situation continued with great challenges after the formation of Malaysia on $16^{\text {th }}$ September 1963. First, Indonesia launched an offensive on Malaysia known as 'Confrontation' in 1965. followed by in 1968, the Communist Party of Malaya launched their second offensive against 
the Malaysian Government through armed struggle known as the Second Insurgency of 1968 to 1989 (Syed Othman, 1999).

Malaysia's security situation in 1970's was complex and full of challenges. Being a newly independent nation, Malaysia had to manage both her own internal and external security issues after the withdrawal of the British Forces. With the experience from the First Emergency, Malaysia was swift to manage her own Counter Insurgency's effort against the CPM. The immediate approach taken by Malaysia established a more coordinated effort from the Federal to the District level by involving all the government mechanism. The Security Forces (SF) was enhanced and strengthened with the combination of the personnel from the Malaysian Armed Forces (MAF) and the Royal Malaysian Police (RMP). The local Government agencies from the District level participated in supporting the Security Forces operations against the Communist Insurgents or commonly known as Communist Terrorists (CTs).

In studying the different levels of strategy, three main levels are identified: Grand Level, Operational and Tactical level. Emphasis is largely placed on Grand and Operational level, being the important levels in overturning the Insurgent activities. However, due to the challenging condition of Malaysian terrain and the Communist insurgents' activities, conduct of operations were demanding for smaller groups operations. The effectiveness of small groups depended on their skills and this is where Intangibles skills play its importance. The Infantry battalions, which formed the backbone of the Malaysian Army, had played a significant role in the Counter Insurgency operations in 1970s. These were soldiers of the Royal Malay Regiments (RMR) and the Royal Rangers Regiment (RRR). The Royal Rangers Regiment consisted of men from all races from the Penisula and various ethnics from Sabah and Sarawak. As rightly being described they were one of those "Great patriots emerge during crisis. Their success in tactical operations was due to their outstanding camouflage and intangible skills.

\section{Problem Statement}

The end of the Malaysian Second Insurgency on 2nd December 1989 gave great opportunity for Malaysia to concentrate on her development. It happened almost during the same period when the Cold War ended in Europe. Putting an Insurgency to an end was not easy. When the CPM were 'defeated' in the First Emergency, a handful of them retreated to South Thailand. They spent almost 8 years reorganizing their Armed or Assault Groups; retraining, recruiting new cadres, getting supplies and renewing their Central Committee's Directive. They returned in June 1968 by launching a brutal ambush on the Security Forces at Kroh Baling Road (Syed Othman, 1993). The Malaysian Security Forces were caught by surprise after an absent of CPM's activities for almost 8 years. This time the CPM came with fresh organization, new tactics and re-new Directive. It seems that the CPM had adopted some of Mao's principles. Mao Tze Tung underlined 3 phases in a Guerrilla fight: Preparatory, Harrasment and Offensive (Baylis et al., 2014). What is important in Mao's theory is that there is no 'time limit' to a particular offensive. 
How did Malaysia manage to suppress and put to an end of the Communist Insurgent Second offensive within a period of 21 years? Was Malaysia then better organized, was her grand strategy smartly designed, did the operational planning and execution went well? Did Malaysia take all lessons learnt from the 12 years of fighting in the First Emergency into practice in the Second Insurgency? Above questions on the success of the Second, Insurgency seemed to neglect the question on the importance of Tactical level of Strategy in the entire period of the Second Insurgency. How committed were the Security Forces (SF) at Tactical Level in supporting the entire operations? As Clausewitz stated, "strategy is done by tactics" (Howard and Paret, 2008) may add to explain the above question. Finally, how did Malaysian Security Forces do it? Bearing in mind the Security Forces' high commitment to run small patrols in vast jungle, rough terrains and adverse weather conditions. To make the situations worst were the regular deaths and casualties of the Security Forces due to CTs' attacks. Yet, despite all the odds, the Security Forces never gave up and continued to strive which eventually led to their success in terminating the Communist struggle in Malaysia.

\section{Research Objectives}

This essay seeks to analyze the practice and employment of tactical operation under the Tactical level of strategy. It will provide the avenue to further study how the tactical operations were organized by the Malaysian Security Forces. How the Security Forces were deployed and given the task to fight the armed Communist Terrorist (CTs) in the 1970s where the intensity of the communist activities seems to occur most. This paper will further seek to analyses the unswerving commitment of the Malaysian Security Forces whilst battling the hard core Communist Insurgents under adverse Malaysian terrain and weather conditions. Despite death, injuries and hardships, these men continued to remain loyal and committed to their cause of duty. Finally, this essay will answer to what lies behind the success of the Security Forces operations, be it the men, weapons, planning and most of all the covert skills of these men namely the Intangibles skills.

\section{Research Methodology}

Luttwak highlighted that in the Tactical Level of Strategy, a wholly new factor may determine the failure and success of a tactical operation within brief span of time; skill. Mechanical working of the weapons may be supported by subtler tactical skills, in order to operate within the terrain, weapons at hand, and particular context of each encounter (Luttwak, 1987). Therefore, successful conduct of operations against well trained and discipline insurgents required great skills; leaders at tactical levels must possess elements of bravery, high morale and courage, which form the Intangible of skills.

This essay will explore the elements of Intangible of skills: bravery, courage, morale and leadership by members of the Security Forces fighting the Communist Insurgents in the 1970s. The study will use phenomenological research method with emphasis on the Hermeneutics model (Moustakas, 1994). This model will look into incident reports, contact reports, operational reports and unpublished documents of the Security Forces against the CTs. These are invaluable and unpublished documents, which reveal the covert skills of the Infantryman from the Malaysian Royal Ranger Regiment. This essay will seek to demonstrate that their Intangibles skills have proven to be effective and demoralizing to the CTs. 


\section{Overview of Malaysia's Security In The 1970's}

The launching of the second offensive by the CPM on 17th Jun 1968 caught the Malaysian Government by surprise, as its occurrence happened barely a year after the end of the Confrontation with Indonesia. Malaysia was facing some level of uncertainty over the future direction on the war in Vietnam. Thus, there were concern between her external defense and immediate concern on the CPM renewed offensive. By then Malaysia was left alone after the British's withdrawal from Malaya. Malaysia had to solely rely on her newly Armed Forces, which was formed in 1963, as her external defense and internal security (Baginda, 2009). While facing the emergence of the CPM's revival, Malaysia was also facing an internal security situation resulted from the Racial Riot of 13th May 1969.

Malaysian Security Forces had to face the Second Insurgency with a different setting against the CPM's new organization and tactics. Although the area of operations were confined towards the northern states of Perlis, Kedah, Kelantan, Perak and Pahang but the intensity of the operations had increased tremendously. The Security Forces were continuously pressured to flush and search the Communist Terrorists. The CTs were getting more aggressive by causing many casualties with their bobby traps and ambushes. At the peak of the operations, the CPM actively operated from the border of Thailand and Malaysia with their Headquarter suspected to be in Betong, Thailand. The CPM even diverted their focus from jungles to town areas when they began to form underground cells in the capital of Kuala Lumpur and other main cities in Penisular Malaysia (Chandran, 1976).

\section{The Armed Struggle by the Communist Party of Malaya (Cpm)}

The launching of the Insurgency against the Malaysian Government in 1968 was mainly due to their success in building up new strength on their armed insurgents (Mohd Reduan, 1993). After an absence of 8 years, the CPM returned with a renewed vision. Their withdrawal to their sanctuary in Southern Thailand in 1960 enabled them to reorganize their armed struggle. In launching their offensive against the Malaysian Government Security Forces, the CPM organized themselves into Regiments and Assault Groups assisted by underground organizations in selected districts in the Penisula. Of prominence were the 8th Regiment, 12th Regiment, 5th Assault Group and 6th Assault Group. The Communist Terrorists (CTs) were operating within small groups under their various Assault Groups in well-selected operation areas. These Assault Groups were living in strategic locations, which were well-concealed and well-guarded camps. They operated from these camps or bases to conduct ambushes and implanted bobby traps to inflict casualties onto the Security Forces. They practiced very strict daily routine with emphasis on security, high jungle skills and high endurance.

They conducted training on new cadres and contacting the masses through their underground contact, the Min Yuen Group. Their practice of high tactical skills left little trail to trace their movements and activities. They maintained a special way of communications such as using Dead Letter Box (DLB) to pass messages between groups (Leong Chee Who, 2012). Their ability to develop bobby traps of various types inflicted many casualties to the Security Forces. Due to limited number of weapons, which were confined to small arms such as carbines, Point 22 rifle, shotguns, they develop sharp shooter skills and efficient use of weapons on contacts. Their high discipline, mental 
and physical endurance, strong will, determination and efficient jungle skills had turned them into hard-core terrorists. Their strong trust in their cause of fighting and undivided belief in their ideology had pushed them to fight according to the way Moa Tze Tung had preached. Mao placed an emphasis "for success to be achieved by the disadvantage side, it was necessary not only to subordinate the military to the political struggle, but also to exploit the advantage of space and time (Berger and Weber, 2011).

\section{Importance of the Tactical Level of Operations}

Tactics as proposed by Clausewitz is the art of using troops in battle; strategy is the art of using battles to win war (Kennedy, 1991). The success stories of the Malaysian soldiers in the 1970s were due to their exceptional skills at small level operations that is at Squad and Platoon levels. These levels were the one, which mostly engaged with the CTs. These platoons and squads were under the command of their respective Battalions, which form the main elements of the Tactical Level. They conducted long-range patrols operating under adverse weather conditions and difficult terrain over a long period. They carried with themselves limited supplies, which required re-suppling according to schedules by helicopters. They were operating at a distance from the Battalion Tactical Headquarter often out of range from support such as artillery, engineer and immediate reinforcement. Taking into considerations on the renewed 'modus operandi' of the CPM's armed struggle, the Malaysian Security Forces had to be more vigilant in their operations. Although, the planning process took place at Operational Level that is at the Corps and Divisional level. At the Tactical Level, operational planning and the conduct of the operations were assigned to the Brigades and the battalions. Security Forces involved in the operations must study and be well-versed with the tactics of the CTs. They needed to understand the pattern of the CTs movement, habits, routine and capabilities. Thus, to counter the CTs, members of the Security Forces, they must be well-trained and ready to face the unexpected.

\section{The Intangibles of Skill - Experience Of the Royal Rangers Regiment}

The Royal Ranger Regiment consisted of infantryman. The Infantryman were described as "they marched back from the battle in the way of an infantry, their feet scarcely leaving the ground, their bodies rocking mechanically from side to side as if that was the only way they could lift their legs." (Royal Military Academy, 1959). The Royal Ranger Regiment had proven their contributions during the Counter Insurgency Operations in the Penisula Malaysia. The regiment was formerly known as "Sarawak Rangers" which began operating under the British Forces in Malays under the First Emergency since 1st January 1953. The soldiers of the Royal Ranger Regiments have been known to have the intangible of skills of courage, leadership, morale and bravery.

Courage is not just merely a moral quality, but also will power. To be great, men must have both forms of courage: physical and morale courage. Morale courage is said to be a more reasoning attitude, which enhances judgement of what is right or worthwhile. Physical courage is an emotional state, which urges a man to risk injury or death (Royal Military Academy, 1959). Winston Churchill eloquently describes courage as "rightly esteemed the first of human qualities because it is the quality 
INTERNATIONAL JOURNAL OF ACADEMIC RESEARCH IN BUSINESS AND SOCIAL SCIENCES

Vol. 9, No. 1, Jan, 2019, E-ISSN: 2222-6990 @ 2019 HRMARS

which guarantees all others. The act of courage as being described earlier could be been seen in the following contact during the Insurgency (Royal Military Academy, 1959).

Warrant Officer Kanang Anak Langkau was serving in the 8th Royal Ranger Regiment as a Platoon Commander. He was involved in the contact with the CTS in the operational area in Perak on February 1980 where he managed to locate the Communists' camp. In that encounter, despite being injured he continued to inspire his men to fight against the CT. His platoon managed to capture the camp and killed 2 CTs. Earlier on, in another contact with the CT on May 1979, in the operational area in Chemor, Perak Kanang Anak Langkau led an assault on CT rest area. In this contact, his platoon managed to kill 5 CTs while 2 of his soldiers were killed. Kanang Anak Langkau was awarded both the Nation's Highest bravery award and the Nation's Second highest bravery award (Kementerian Pertahanan), Kanang Anak Langkau demonstrated a great moral quality, the will power to continue fighting despite his injury and moral quality which led his men to success.

Leadership is defined as "the will to dominate, together with the character which inspires confidence." Therefore, a leader has to learn to dominate the events, which surround him and be prepared to accept responsibility (Royal Military Academy, 1959). During the Counter Insurgency Operation in 1970's, one of the fine examples of a leadership quality was exemplified by Captain Shanmuganathan Ampopoo. He was involved in a military operation in Pahang in December 1973. He was then serving in the 5th Royal Regiment Rangers. The Platoon under his command found traces of CTs movement and set to trail the movement of the CT group continuously for 3 days. His ability as a commander and outstanding tactical knowledge managed to track the CT movement. On finding the CT's location on the evening of the third day, he quickly organised a hasty attack. He was killed during the attack, along with another brave soldier. Captain Shanmuganathan Ampopoo and his soldier Ranger Mat Isa Hassan were both posthumously awarded the Second Nation's Highest Gallantry award (Royal Military Academy, 1959). Captain Shanmuganathan Ampopoo had the ability to command the entire situation to track the CTs movement without losing the suprise. As a leader, he was quick enough to react in leading an attack although he got killed in the attack.

Morale is a state of mind. It is that intangible force which will move a whole group of men to give their last ounce to keep on striving, at all cost. High morale makes them feel that they are part of something greater than themselves (Royal Military Academy, 1959). Another remarkable contact with the CTs that took place in the early 1970's is related to this intangibles of skill, that is morale. The late Captain Chandran Mohan was serving in the 4th Royal Ranger Regiment. He was involved in a special operation in an operational area in Perak in June 1971. In this special operation, Captain Chandran and his platoon managed to locate a well-fortified CT camp. He managed to move his platoon close to the CT camp. He made a plan to attack the CT Camp and led his men to attack the camp. He was killed in the attack but his men continued to complete the attack. He was post posthumously awarded the Nation's highest Gallantry award (Royal Military Academy, 1959). Captain Chandran Mohan ability along with men in locating one of the prominent CT Camp required not only skills but also the confidence and trust of his men. And with the high morale of the entire Platoon 
under his command had allowed Captain Chandran Mohan to lead the assault on a prominent CT Camp although he got killed in the attack.

Bravery. Clausewitz, when discussing military virtues of the army highlighted that Military virtues should not be confused with simple bravery and enthusiasm for a cause. Bravery is obviously a necessary component. Bravery, which is part of the natural make-up of the man's character can be developed in him (Royal Military Academy, 1959). The skill of bravery can be seen in two separate contacts of the Security Forces against the insurgents. A bravery act of Sergeant Micheal Riman from the 8th Royal Ranger Regiment was one of the special Squad Section Commanders. His platoon encountered a group of CT on June 1979 in one of the operational areas in Perak. Sargeant Micheal had two previous direct contact experiences with the CT and was once injured in the arm. In this contact, his act of bravery managed to help his Squad to successfully kill a group of CTs. He was awarded the Nation's Second Highest Bravery award (Ibid). In an another separate contact in November 1974 at the Operational area in Pahang, Platoon under 5th Royal Ranger Regiment commanded by Second Lieutenant Basri Bin Din conducted an ambush on the CTs. With his bravery, good planning, his ambush party managed to kill one CT in the fire fight. He was awarded the Nation's Second Highest Bravery Award (Othman,1993). Based on these two incidents, it was evident that just a 'simple bravery' will not be able to achieve a positive result in the fight against the insurgents.

\section{The End of the Insurgency}

The Second Malaysian Insurgency ended on 2nd December 1989, witnessed by signing of the Peace Accord. The insurgency covers a total period of 21 years and 5 months. On the Malaysian Security Forces side a total of 155 were killed whereas 854 were wounded. The CPM began their offensive with almost 8,000 strengths. At the end of the Insurgency 212 killed, 117 surrendered and 150 captured. There are many reasons that contributed towards the end of the insurgency. First, on the tactical level, the pressure by the Malaysian Security Forces had given the CPM little space to manouvre. Their underground contacts and supporters were becoming smaller. They were short of supplies, food, weapons, medicines and financial support. Second, on the Strategic level, the strong bilateral relation between the Government of Malaysia and Republic of China rendered the CPM from getting support from China. Third, the decline of the Soviet Union had caused the communist no longer getting international support from them. The Counter insurgency effort by the Malaysian Government had been very costly, exhaustive and involved many agencies. The application of tactical level of operations in the 1970s contributed significantly in bringing the end of the CPM's armed struggle against the Malaysian government.

\section{Conclusion}

This essay has highlighted three main issues. First, it demonstrates that Level of Strategy is important in dealing with nation's security. By understanding, the importance of each level can contribute towards a comprehensive and successful end in curbing war against the Insurgents or Guerrilla. Within the Malaysian environment, the Counter Insurgency Strategy is done at the highest level. The operational level is coordinated with the counter-insurgency effort. By virtue that the CTs were operating on a small group, therefore the Tactical Level played a significant role in engaging the CTs. 
Second, in conducting small groups operations, it depends heavily on the performance of the members of the Security Forces. Being in dense jungle, far away from immediate reinforcement they had to work closely together. This is when the useful skills of the members of the Security Forces, that is the intangible skills influence the result of the operations. The contact experiences as discussed above demonstrated the need to stand together under all extreme conditions. Intangible skills such as morale, leadership, bravery and courage did change the direction of the counter insurgency planning. Harassment, damage, death and injuries received by the Insurgent became the driving factors towards ending the Insurgency. Finally, the continuous harassment and sabotage by the CTs on development project did not deter the Malaysian Government to slow its development phase. With high commitment from the members of the Security Forces and the support given by the people of Malaysia has continued to progress despite having to fight against the armed struggle of the Communist Party of Malaya (CPM).

\section{Lessons Learnt}

Despite all the tough years that Malaysia had to endure in bringing to the end of the insurgency yet there are things that could be considered as lessons learnt. First, Insurgency differs from one country to another as the 'cause' of the conflict is dissimilar. Similarly, process and effort to bring the insurgency to an end are not the same. It is acknowledged that not all countries in the world have been successful in managing insurgencies. Secondly, counter-insurgency's effort is not solely the responsibility of the Government and the Armed Forces alone. The creation of the term "Security Forces" in the Malaysian context allows all members of the security and non-security organization to work collaboratively in fighting a common enemy. Starting from the Federal level, that is the National Security Council to the lowest level that is the District Security Committee level, every agency gave their utmost cooperation. For example, the Forest Department on rounds at their respective Forest Reserve areas would notify the Security Forces whenever they encountered any information about CT's activities. Third, Malaysia has established that Security and Development must go hand in hand. There must be a strong cooperation between them. Development and security has sped up the process of Counter Insurgency's effort. Fourth, the Operational experiences that the Security Forces had gone through develop their professionalism in the Counter-Insurgency operations. Finally, it should be acknowledged that the intangible of skills which consist of courage, leadership, morale and bravery have made important names to the Royal Rangers Regiment along with other members of the Security Forces in the entire counter Insurgency period. The numerous gallantry awards particularly the Nation's highest gallantry award (Grand Knight of Valour) and the second highest Nation's gallantry award (General Bravery and Valour) have given members of the Rangers great pride in their uncompromising struggle against the Communist Terrorists (CTs). The famous 'war cry' of the Royal Rangers Regiment Agi Idup Agi Ngelaban will remains to be remembered as the main motivator and inspiration in their struggle to return the peace and stability to their beloved nation.

\section{Acknowledgement}

The authors wish to express gratitude to National Defense University of Malaysia for funding support. 
INTERNATIONAL JOURNAL OF ACADEMIC RESEARCH IN BUSINESS AND SOCIAL SCIENCES

Vol. 9, No. 1, Jan, 2019, E-ISSN: 2222-6990 (C) 2019 HRMARS

\section{References}

Baginda, A. R. (2009). Malaysia's defence and security since 1957. Kuala Lumpur: MRSC.

Baylis, J., Wirtz, J. J., \& Gray, C. S. (2014) Strategy in the contemporary world. United Kingdom:

Oxford University Press.

Berger, M. T., \& Weber, H. (2011). War, peace and progress in the 21st century. London: Routledge Tailor \& Francis.

Howard, M., \& Paret, P. (2008). On war. (Clausewitz C.V., Trans.). New York: Oxford University

Press.

Jeshurun, C. (1976). The security "gap" in Peninsular Malaysia. Southeast Asian Affairs, 234-241.

Retrieved from http://www.jstor.org/stable/27908282

Kennedy, P. (1991). Grand strategies in war and peace. New Haven: Yale University.

Luttwak, E. N. (1987) Strategy, the logic of war and peace. London: Harvard University Press.

Asli, M. R. (1993). Pemberontakan bersenjata komunis di Malaysia. Kuala Lumpur: Dewan Bahasa dan Pustaka.

Moustakas, C. (1994). Phenomenological Research Methods. London: SAGE Publications.

Royal Military Academy. (1959). An anthology: Serve to lead, Compiled by Royal Military Academy, to all cadets at Sandhurst. United Kingdom.

Othman, S. (1999). Tentera Malaysia dalam era Konfrontasi. Bangi: Penerbit Universiti Kebangsaan Malaysia.

Othman, S. (1993). Pahlawan angkatan tentera: Penerima S.P. \& P.G.B., Jilid 2. Kuala Lumpur:

Dewan Pustaka dan Pustaka.

Leong, C. W. (2012). Scorpio of the dragon demise: The Second Malayan Communist Insurgency 1970-1990. USA: Rocky Mountain Press. 